$\frac{\text { DE }}{\text { DE GRUYTER }}$ OPEN

\title{
DETERMINANTS OF ACCESS TO FORMAL CREDIT BY THE POOR HOUSEHOLDS
}

\section{Mduduzi BIYASE*}

University of Johannesburg, South Africa

\section{Bianca FISHER}

University of Johannesburg, South Africa

\begin{abstract}
This paper investigates the determinants of access to formal credit by poor households in South Africa. Despite some progress in poverty reduction in the recent years, it remains astonishingly high by historical and international standards. Access to credit is believed by some scholars to be a primary means to address poverty and improve the standards of living of poor households. Thus, it is necessary to identify the determinants of the propensity to borrow and of the amount that is borrowed. Using 2008-2012 data from the National Income Dynamics Study (NIDS), a Heckman Selection model was estimated. The results from this study suggest that age of the household head, race, educational level, gender, employment, geographic location of households affect the propensity to borrow by poor households in South Africa.
\end{abstract}

JEL classification: D12, 012

Keywords: formal credit, poor households, Heckman selection and NIDS

\section{Introduction}

Despite the well-established and effectively regulated South African banking system, many low-income or poor households do not have access to credit services. There are several reasons for this: (i) poor households are regarded as risky and unprofitable (ii) the low levels of saving and asset accumulation in the low-income population render them to have a high risk profile, thus making them unattractive to commercial banks (iii) commercial banks are likely to incur high information costs to assess the creditworthiness poor households (Dallimore and Mgimeti, 2003; Mashigo 2007 and Okurut 2006).

\footnotetext{
* Corresponding author. Faculty of Economics and Financial Sciences University of Johannesburg, adddress: Protea Glen ext 12, 1818, South Africa, Email: mbiyase@uj.ac.za
} 
Access to credit can play an important role in the lives of the low-income or poor households as it allows them to cope better with various types of shocks (such as illness, malnutrition, famine, crime, unemployment, financial crisis and natural disasters), thus ameliorating socio-economic problems (Mashigo 2007; Zeller 1994; Islam and Maitra 2012; Vicarelli 2010; Morduch 1995; Gertler, Levine and Moretti 2009). A forceful proponent of this view is Seefeldt (2015:263) who found evidence to suggest that access to credit can "increase consumption beyond what one's income can support, it can smooth consumption during periods when income falls, and it can represent an investment in the future".

Much work has been done on the determinants of credit market access in developed and developing countries (see for example Anang, Sipiläinen; Bäckman and Kola (2015); Quoc (2012); Kedir (2003); Zeller, Schrieder, von Braun and Heidhues (1997); Zeller (1994); Omonona, Lawal, and Oyinlana (2010), Hussein and Ohlmer (2008); Oyedele, Akintola, Raji and Omonona (2009). However, few studies have been conducted in the South African context (Baiyegunhi, Fraser and Darroch 2008; Mashigo 2007 and Okurut 2006). Moreover, studies employing suitable techniques of assessing the determinants of access to formal credit by poor households are limited. Thus the contribution of this paper is twofold: we propose and implement an econometric framework which seeks to overcome the shortcomings of the research methodology employed in previous studies. Specifically, we correct for possible selection bias and unobserved heterogeneity in the panel data setting by estimating a model (or panel Heckman selection) proposed by Wooldridge (1995). Secondly, this paper attempts to address some of the deficiencies associated with cross-sectinal data by using the National Income Dynamics (NIDS) dataset, a nationally representative survey of households in South Africa.

The remainder of this paper is organized as follows. Section 2 examines existing literature applicable to this topic. Section 3 explains the data and explanatory variables used in the empirical analysis. Section 4 sets out the methodology used. Section 5 presents the results obtained using the Heckman selection model. Finally, section 6 provides a summary and conclusion.

\section{Literature Review}

There is extensive literature on the determinants of access to credit in many countries (see Anang, Sipiläinen; Bäckman and Kola 2015; Quoc 2012; Kedir 2003; Zeller, Schrieder, von Braun and Heidhues 1997; Zeller 1994; Omonona, Lawal, and Oyinlana 2010, Hussein and Ohlmer 2008; Oyedele, Akintola, Raji and Omonona 2009). For example, Quoc (2012) estimated a double hurdle model and the Heckman selection model using data from a survey of 325 rural households in Vietnam. The results of the double hurdle model and the Heckman analysis show that household's capital endowments are important determinants of the demand for formal credit as well as the loan amount. The results also show that the probability to borrow is influenced by marital status and distance to the market centre.

Using both Tobit and probit, Kedir (2003) estimated the determinants of access to credit and loan amount in Ethiopia. His estimates suggest that the main 
determinants are current resources, collateral, outstanding debt and marital status of the head. Baffoe and Matsuda (2015) also implemented a binary method (probit) to the determinants of access to credit. They found that the most important variables are livelihood diversification, household productivity, savings accounts and household size - factors that significantly influence the households' ability to access credit.

Education levels were consistently found to have a significant and positive effect on household's access to credit (Okurut 2006; Vaessen 2001; and Kedir 2003). Evidence from Vietnam suggests that levels of household expenditure/income and asset are important determinants of the propensity to borrow by rural households and the amount of the loan received ( $\mathrm{Ha}, 1999 ; \mathrm{Ha}, 2001)$. Evidence from South Africa show that access to semi-formal credit in South Africa is positively and significantly affected by household size, per capita expenditure, provincial location and being coloured, while the negative and significant factors include rural location, being poor and White Okurut (2006).

However, the evidence on most determinants is mixed. In particular, the influence of gender is inconclusive. Some studies find that male is more likely to be credit constrained (Okurut 2006 Barslund \& Tarp, 2008; Chaudhuri \& Cherical, 2011; Freeman, Ehui, and Jabbar 1998; Zeller, 1994) while Lawal and Muyiwa, 2009 Foltz et al., 2000 show the inverse result.

Some studies also provide mixed results on the influence of age. For example, Barslund and Tarp (2008) Freeman, Ehui, and Jabbar (1998) and Jia et al. (2010) find an inverse correlation between age and probability of being credit constrained, while Baiyegunhi et al. (2010) and Chaudhuri et al. (2011) find different results.

\section{Data Source}

Our econometric analysis is based on the National Income Dynamics Study (balanced panel data) of South African households observed over the period 20082012. The longitudinal survey was conducted by the Southern African Labour and Development Research Unit (SALDRU), based at the University of Cape Town's School of Economics. The NIDS commenced in 2008 with over 28000 individuals in 7300 households across the country. The later waves of the NIDS were implemented in 2010 and 2012, and re-surveyed original NIDS wave1 households. NIDS data comprise comprehensive set of variables (e.g. credit, employment, income, wealth, race dummies, and province dummies) which are important for our study.

In addition to the dependent variables (access to formal credit and the amount of credit), we use several control variables in our econometric analysis. Table 1 provides a list of all the variables used. Our choice of control variables (see Table 1) is informed by the ones used in the existing empirical literature. Specifically, we control for socioeconomic and demographic characteristics (age, gender, household income, asset ownership and levels of education), household composition characteristics (household size) and geographical variables (province dummies and indicator variables for location of the household-rural or urban). 
Table 1: Explanatory variables used in the empirical analysis

\begin{tabular}{|c|c|c|}
\hline Variables & Type & Description \\
\hline \multicolumn{3}{|l|}{ Dependent variable } \\
\hline Access to formal credit & Dummy & $1=$ Access to formal credit, $0=$ Otherwise \\
\hline Loan (log) & Continuous & Amount of formal credit (log) \\
\hline \multicolumn{3}{|l|}{ Explanatory variables } \\
\hline Age of $\mathrm{HH}$ head & Continuous & Age of $\mathrm{HH}$ head (in years) \\
\hline Age SQ & Continuous & Age squared \\
\hline Asset ownership & dummy & own assets $(1 / 0)$ \\
\hline Income & Continuous & Amount of income earned(in rand) \\
\hline Size of $\mathrm{HH}$ & Continuous & Total number of members in $\mathrm{HH}$ \\
\hline Coloured & Dummy & 1=Coloured $\mathrm{HH}$ ead, $0=$ Otherwise \\
\hline Indian & Dummy & $1=$ Indian $\mathrm{HH}$ head, $0=$ Otherwise \\
\hline White & Dummy & $1=$ White $\mathrm{HH}$ head, $0=$ Otherwise \\
\hline Primary education & Dummy & $\begin{array}{l}1=\mathrm{HHH} \text { with primary education, } \\
0=\text { Otherwise }\end{array}$ \\
\hline Secondary education & Dummy & $\begin{array}{l}1=\mathrm{HHH} \text { with secondary education, } \\
0=\text { Otherwise }\end{array}$ \\
\hline Tertiary education & Dummy & $\begin{array}{l}1=\mathrm{HHH} \text { with tertiary education, } \\
0=\text { Otherwise }\end{array}$ \\
\hline Matric & Dummy & $1=\mathrm{HHH}$ with matric, $0=$ Otherwise \\
\hline Gender of $\mathrm{HH}$ head & Dummy & $1=$ Female, $0=$ Otherwise \\
\hline Employment status of $\mathrm{HHH}$ & Dummy & 1= Employed $0=$ Otherwise \\
\hline Urban & Dummy & $\mathrm{HH}$ in urban areas \\
\hline Farm & Dummy & $\mathrm{HH}$ in farm areas \\
\hline Eastern Cape & Dummy & $\mathrm{HH}$ in Eastern Cape \\
\hline Northern Cape & Dummy & HH in Northern Cape \\
\hline Free State & Dummy & $\mathrm{HH}$ in Free State \\
\hline KwaZulu-Natal & Dummy & $\mathrm{HH}$ in KwaZulu-Natal \\
\hline North West & Dummy & $\mathrm{HH}$ in North West \\
\hline Gauteng & Dummy & $\mathrm{HH}$ in Gauteng \\
\hline Mpumalanga & Dummy & $\mathrm{HH}$ in Mpumalanga \\
\hline Limpopo & Dummy & HH in Limpopo \\
\hline
\end{tabular}

Income was deflated using the national Consumer Price Index of South Africa at constant 2008

Table 2 presents the descriptive statistics of the dependent and independent variables (sample of poor households). The data shows that over the three waves, the mean loan amount accessed by households increased from $0.7 \%$ in 2008 to $1 \%$ 
in 2012. The mean monthly income received by households rose considerably from R278 in 2008 to R365 in 2012. Household size was stable across the three periods with an average of 7 members, whereas, the average number of household heads that obtained a primary education fell from $45.2 \%$ in 2008 to $37.8 \%$ in 2012 . On average, the number of household heads that were employed fell from $11.8 \%$ in 2008 to $10.1 \%$ in 2012 . The proportion of households headed by females increased from $57 \%$ in 2008 to $71.5 \%$ in 2012 .

Table 2: Summary statistics of variables used in the regressions, 2008-2012

\begin{tabular}{lllllll}
\hline \multirow{2}{*}{ Variable } & \multicolumn{2}{c}{$\mathbf{2 0 0 8}$} & \multicolumn{2}{c}{$\mathbf{2 0 1 0}$} & \multicolumn{2}{c}{2012} \\
\cline { 2 - 7 } & Mean & Std dev. & Mean & Std dev. & Mean & Std dev. \\
\hline Access to a loan & 0.007 & 0.082 & 0.012 & 0.108 & 0.010 & 0.100 \\
HHH_age & 46 & 15 & 46 & 15 & 44 & 15 \\
HH_income & 278 & 127 & 333 & 151 & 365.015 & 142. \\
HH_size & 7 & 3.639 & 7 & 3.677 & 7 & 3.479 \\
HHH_empl & 0.118 & 0.323 & 0.093 & 0.290 & 0.101 & 0.301 \\
HHH_gender & 0.570 & 0.495 & 0.658 & 0.475 & 0.715 & 0.452 \\
Coloured & 0.053 & 0.224 & 0.051 & 0.220 & 0.049 & 0.216 \\
Indian & 0.004 & 0.062 & 0.004 & 0.066 & 0.002 & 0.039 \\
White & 0.003 & 0.054 & 0.004 & 0.067 & 0.003 & 0.053 \\
Primary education & 0.452 & 0.498 & 0.380 & 0.485 & 0.378 & 0.485 \\
Secondary education & 0.272 & 0.445 & 0.293 & 0.455 & 0.306 & 0.461 \\
Matric education & 0.080 & 0.272 & 0.087 & 0.281 & 0.085 & 0.279 \\
Tertiary education & 0.014 & 0.116 & 0.021 & 0.144 & 0.013 & 0.113 \\
Rural/traditional areas & 0.535 & 0.499 & 0.523 & 0.499 & 0.536 & 0.499 \\
Urban & 0.394 & 0.488 & 0.407 & 0.491 & 0.401 & 0.490 \\
\hline
\end{tabular}

Source: author's calculations using NIDS data

\section{Methodology}

Our empirical investigation is based on the estimation of the well-known Heckman selection model, which takes into consideration sample selection bias (due to non-random decision of household to participate in credit market and other related issues). In the presence of sample selection bias, OLS is likely to yield spurious results (i.e. biased and inconsistent). While the Heckman sample selection model is more frequently used in studies based on cross-section data, it is not appropriate in panel data settings. Thus to correct for the potential sample selection bias we employ the Wooldridge (1995) selection method that extends traditional Heckman selection model to a panel data. The Wooldridge (1995) selection method is similar to the 
traditional Heckman selection model in that it is estimated in two stages. First it estimate a probit equation (the probability of receiving a loan in our case) and a Pooled OLS (for the amount of the loan in our case), including the Mills ratio.

Thus, the Wooldridge (1995) selection model can be expressed as follows:

Participation equation:

$$
C_{i t}^{*}=x_{1 i t} \beta_{1}+\forall_{i}+\varepsilon_{1 i t}
$$

Participation equation describes the probability of a household receiving a loan $\left(C_{i t}^{*}\right)$ as influenced by a set of independent variables $X_{i t}$ (such as age, gender, household income, asset ownership, levels of education, household size, province dummies and indicator variables for location of the household - rural or urban). While $\forall_{i}$ denotes individual-specific time-invariant unobservables. The participation equation is estimated by a probit model. $C_{i t}^{*}$ is a dichotomous variable that takes a value of 1 if the household receives a loan, and 0 otherwise.

More formally, we have

$$
\begin{gathered}
C_{i}=1 \text { if } C_{i}^{*}>0 \\
0 \text { if } C_{i}^{*} \leq 0
\end{gathered}
$$

Outcome equation:

$$
Y_{i t}^{*}=x_{2 i t} \beta 2+\forall_{i}+\varphi_{i t}+\varepsilon_{2 i t}
$$

The outcome equation describes the determinants of the amount of household's loans. $Y_{i t}^{*}$ shows the amount of household loans, $x_{2 i t}$ indicate the factors affecting the amount of household loans, and $\varphi_{i t}$ are the inverse Mills ratios estimated in the first selection stage using the probit model for each year. $\varepsilon_{1 i t}$ and $\varepsilon_{2 i t}$ follow a normal distribution $-\mathrm{N}(0,1)$ and $\mathrm{N}(0, \sigma \varepsilon)$, respectively.

\section{Empirical Results}

Table 3 reports the estimation results from the Heckman selection model. The coefficient of the Mills ratio is found to be statistically significant, implying the presence of the selection bias and, thus justifying the application of Heckman selection model. What stands out from the table is that a number of explanatory variables in the participation equation are statistically significant at 10 percent or lower level, with their expected signs. In accordance with a priori expectations the participation equation results suggest that education of the household head is an important determinant of the probability of receiving a loan (three of the four possible education levels are statistically significant in the participation equation) consistent with the findings of Okurut (2006), Vaessen (2001) and Kedir (2003). 
Regarding employment status, the households where the head of the household is employed is more likely to be approved for loans than their counterpart, in line with previous findings in the literature (Fidrmuc et al. 2013). Likewise, the probability of receiving a loan is positively correlated with household income and assets, although the coefficients are statistically insignificant, a similar result was found by Sorokina (2013). Gender (female) of the household head enters with its predicted negative sign at the highly statistically significant level - female are less likely to be approved for loans than man. This result is in line with other existing studies such as Oyedele, Akintola, Raji and Omonona (2009). There are exceptions in the literature, however, as shown by D'Espallier, Guérin and Mersland (2009).

With regards to geographic variables, it was found that both household geotype and provincial location influence the probability of obtaining access to formal credit in South Africa. Specifically, households living in the poorest provinces (Eastern Cape, Kwazulu Natal, Limpopo etc,) are less likely to be approved for the loan than those residing in the Western Cape. Surprisingly, the Northern Cape was the only province that was found to improve the propensity to borrow, however it was not found to be significant. Along the same lines, households living in traditional rural areas and farm areas are less likely to be approved for the loan than households in urban neighbourhoods. This result is anticipated because urban households are predicted to have higher levels of income and wealth and are therefore viewed as more creditworthy

Column three of Table 3 shows the determinants of the amount of the loan received. It can be seen that there are remarkable differences in the parameter estimates of the variables in participation equation and outcome equation. For example, some of the variables appearing in these equations have conflicting effects in terms of both signs and level of significance. Most of the parameters (such as household income and wealth, whether the head of the household is employed, whether the head of the household is male or female, household size and race dummies) that were statistically significant in the participation equation are no longer significant in the outcome equation of the Heckman selection model. The sign for certain variables such as education levels, and Northern Cape Province changed in the outcome equation. The differences in parameter estimates of the variables in participation equation and outcome equation confirm the fact that the decision to borrow and the decision on the amount are not made simultaneously - they are not explained by the same factors.

Table 3: Panel Heckman selection model estimates of the determinants of access to formal credit by poor households in South Africa

\begin{tabular}{lllll}
\hline & \multicolumn{2}{c}{ Participation equation } & \multicolumn{2}{c}{ Outcome equation } \\
\hline Variables & Coef. & Rob. & \multirow{2}{*}{ Coef. } & Rob. \\
\cline { 2 - 5 } & & Std. Err. & & Std. Err. \\
\hline Age of HHH & $0.1265826^{* * *}$ & 0.0393013 & & \\
Age SQ & $-0.0012274^{* * *}$ & 0.0004204 & & \\
Asset ownership & 0.0666691 & 0.0576382 & 0,0035572 & 0,8143747 \\
\hline
\end{tabular}




\begin{tabular}{|c|c|c|c|c|}
\hline \multirow{3}{*}{ Variables } & \multicolumn{2}{|c|}{ Participation equation } & \multicolumn{2}{|c|}{ Outcome equation } \\
\hline & Coef & Rob. & Conf & Rob. \\
\hline & coel. & Std. Err. & Coel. & Std. Err. \\
\hline Income & 0.1467037 & 0.1004438 & 0,2099511 & 0,2343073 \\
\hline Size of $\mathrm{HH}$ & 0.0142573 & 0.0260586 & 0,0698138 & 0,0531952 \\
\hline Coloured & $-0.6647291^{* * *}$ & 0.2475982 & $-0,8782707$ & 0,6264319 \\
\hline Primary & $0.4901221^{* *}$ & 0.2308865 & $-0,3169149$ & 0,4641351 \\
\hline Secondary & $0.6604904^{* * *}$ & 0.2505928 & $-0,1899239$ & 0,4510873 \\
\hline Tertiary & $0.9692691^{* * *}$ & 0.286741 & $-0,1501453$ & 0,5796951 \\
\hline Matric & 0.2774267 & 0.4515922 & $-0,2765149$ & 0,8618749 \\
\hline Gender & $-0.4159641^{* * *}$ & 0.1249802 & $-0,0081419$ & 0,3204073 \\
\hline Employment & $0.187946^{\star}$ & 0.1037089 & 0,0411134 & 0,3159033 \\
\hline Urban & $0.5257752^{* * *}$ & 0.1573747 & 0,2227421 & 0,4038616 \\
\hline Farm & -0.0078894 & 0.2543639 & $1,334874^{* * *}$ & 0,3754075 \\
\hline Eastern Cape & $-0.9341571^{* * *}$ & 0.2827325 & $-0,4362408$ & 0,8030133 \\
\hline Northern Cape & 0.0036328 & 0.2415262 & $-2,916314^{* * *}$ & 0,7424952 \\
\hline Free State & $-0.7073709^{* * *}$ & 0.2634206 & $-0,8035216$ & 0,8765267 \\
\hline KwaZulu-Natal & $-0.4834772^{* *}$ & 0.2430332 & $-0,7080882$ & 0,7352048 \\
\hline North West & -0.3892125 & 0.2680546 & $-1,446433$ & 0,8861254 \\
\hline Gauteng & $-0.5239795^{* *}$ & 0.2399221 & $-0,4606594$ & 0,8924259 \\
\hline Mpumalanga & -0.4513028 & 0.2798945 & $-0,6745748$ & 0,9112239 \\
\hline Limpopo & $-0.8121656^{* *}$ & 0.3381386 & $-0,2215831$ & 0,8973172 \\
\hline Constant & -6.695918 & 1.275649 & 3,539753 & 3,17208 \\
\hline Wave 2 & $0.1740624^{* *}$ & 0.0858532 & $-0,2138409$ & 0,3085567 \\
\hline Wave 3 & -0.0688128 & 0.1195086 & $0,974978^{* * *}$ & 0,4961136 \\
\hline Mills ratio & & & $0,3862088^{* *}$ & 0,1522697 \\
\hline
\end{tabular}

Adjusted R-squared 0.6373

Heteroscedasticity Test $^{\dagger}(0.0000)$

$(0.0000)$

Note: * Significant at $10 \%,{ }^{* *}$ Significant at $5 \%,{ }^{* * *}$ Significant at $1 \%$

Source: author's calculations using NIDS data

\section{Conclusions}

In this paper, we investigated the determinants of access to formal credit by poor households in South Africa. We corrected for possible selection bias and unobserved heterogeneity in the panel data by estimating a model proposed by Wooldridge (1995). Our results provide valuable insights into the determinants of access to formal credit. We found a number of variables, namely, age of the household head, race dummies,

\footnotetext{
$\dagger$ Further specification tests such as autocorrelation and heteroscedasticity tests were undertaken and their existence is confirmed, the model has been adjusted using cluster the standard errors. The coefficients and the adjusted standard errors for all the models are reported in Table 3.
} 
educational levels, gender, employment, geographic location of households, to have a significant impact on propensity to borrow. Interestingly, households living in the poorest provinces (Eastern Cape, Kwazulu Natal, Limpopo etc,) were less likely to be approved for the loan than those residing in the Western Cape. Along the same lines, households living in traditional rural areas and farm areas were less likely to be approved for the loan than households in urban neighbourhoods. Our results confirm that the fact that credit market in South Africa have been less successful in providing credit to the poor households. What can be done to promote adequate access to financial services by the poor households? A number of interesting policy options have been proposed in the literature (see Mashigo 2007, Mujeri (2015) and Ksoll et al 2013). The one that stands out is by Mujeri (2015) who takes the view that government should entice financial institutions to enter the rural finance market by providing banks with monetary incentives which help cover the initial costs of entering this risky market. Moreover, given the astonishingly higher levels of poverty and unemployment in South Africa, it goes without saying that improved access to organized credit markets (i.e formal and semi-formal credit markets) by the poor rural dwellers (traditional rural areas) should be considered as an important policy instrument. Our study has shed some light on access to formal credit by rural households, with much less focus on semi-formal credit and informal credit (specifically referred to debts from relatives and friends). Further studies to analyse this aspect would be important.

\section{References}

Anang, B.T., Sipiläinen, T., Bäckman, S., Kola, J. (2015) Factors influencing smallholder farmers' access to agricultural microcredit in Northern Ghana, African Journal of Agricultural Research: 10(24), pp. 2460-2469.

Baffoe, G., Matsuda, H. (2015) Understanding the Determinants of Rural Credit Accessibility: The Case of Ehiaminchini, Fanteakwa District, Ghana. Journal of Sustainable Development, 8: 183.

Baiyegunhi, L. J. S., Fraser, G. C. G., Darroch, M. A. G. (2008) Access to credit and the effect of credit constraints on household welfare in the Eastern Cape Province, South Africa, African Journal of Agricultural Research 2010, 5(16), pp. 22432252.

Barslund, M and Tarp F. (2008) Formal and informal rural credit in four provinces of Vietnam", in: Journal of Development Studies, 44(4): 485-503.

Chaudhuri, K., Cherical, M. M. (2011) Credit rationing in rural credit markets of India. Applied Economics, 44(7): 803-812.

D’Espallier, B., Guérin. I., Mersland, R. (2009) Women and Repayment in Microfinance, Working Paper RUME no. 2009-02, Provence University/RUME Project, Marseille.

Dallimore, A., Mgimeti, M. (2003) Democratic Banking in the New South Africa: Challenging Contemporary Banking Practices at Grass Roots, Unpublished Report, Durban: Development Research Africa, February, 2003.

Fidrmuc, J., Hake, M., Stix, H., (2013) Households' foreign currency borrowing in Central and Eastern Europe. Journal of Banking and Finance 37, 1880-1897. 
Foltz, J., B. Larson, R. Lopez. (2000) Land tenure, investment, and agricultural production in Nicaragua. Development Discussion Paper No. 738, Institute for International Development, Cambridge, MA, Harvard University.

Freeman, H. A., Ehui, S. K., Jabbar, M. A. (1998) Credit constraints and smallholder dairy production in the East African highlands: application of a switching regression model. Agricultural Economics, 19(1-2): 33-44.

Gertler, P., Levine, D. I., Moretti, E. (2009) Do microfinance programs help families insure consumption against illness? Health Economics, 18: 257-273.

Ha, N. T. T. (1999) An analysis of informal versus formal microfinance for the poor in Vietnam. The Vietnamese - Netherlands Master's program in development economics, Class 6 (1999-2001).

Ha, V.T. T. (2001) Determinants of Rural Households' Borrowing from the Formal Financial Sector: A study of the rural credit market in Red river delta region.

Hussein, H.K., Ohlmer, B.O. (2008) Influence of Credit Constraint on production efficiency: The Case of Farm Households in Southern Ethiopia, Department of economics, Swedish University of Agricultural Sciences Sweden.

Islam, A., Maitra, P. (2012) Health shocks and consumption smoothing in rural households: Does microcredit have a role to play?, Journal of Development Economics, 97 (2), pp. 232-243.

Jia, X., Heidhues, F., Zeller, M. (2010) Credit rationing of rural households in China. Agricultural Finance Review, 70(1): 37-54.

Kedir, A. (2003) Determinants of Access to Credit and Loan Amount: Householdlevel Evidence from Urban Ethiopia", International Conference on African Development Archives, Paper 64.

Ksoll, M., Prilla, M., Herrmann, T., Rashid, A., Zentek, T., Strehler, M. (2013) Virtual Living AALLösungen spielend im Alltag verstehen. In Mensch \& Computer Workshopband: 383-389.

Lawal, J., A. Muyiwa. (2009) Food security and socioeconomic characteristics of cocoa farming households in Nigeria: support through agricultural biotechnology. Proceedings of the 2nd International e-Conference on Agricultural BioSciences.

Mashigo, M.P. (2007) Extending credit to the low-income and poor households in South Africa: A system of principles, Thesis, University of Johannesburg, South Africa.

Morduch, J. (1995) Income Smoothing and Consumption Smoothing, Harvard Institute of Economic Research Working Papers 1727, Harvard - Institute of Economic Research.

Mujeri M.K. (2015) Improving Access of the Poor to Financial Services. General Economics Division of the Planning Commission, Bangladesh.

Okurut, F. N. (2006) Access to Credit by the Poor in South Africa: Evidence from household survey date 1995 and 2000", Working Papers 13/2006, Stellenbosch University, Department of Economics.

Omonona, B. T., Lawal, J. O., and Oyinlana, A. O. (2010) Determinants of Credit Constraint Conditions and Production Efficiency among Farming Households in Southwestern Nigeria, African Association of Agricultural Economists (AAAE), Cape Town, South Africa http://purl.umn.edu/95775.

Oyedele, G. A., Akintola, J. O., Raji, M. A. Y., Omonona, B. Y. (2009) Credit constrained condition of farm households and profitability of Agricultural production in Nigeria agriculture, Agricultural Journal, Vol. 4(4), pp.192-201. 
Quoc, D.V. (2012) Determinants of household access to formal credit in the rural areas of the Mekong Delta, Vietnam. African and Asian studies, 11: 261-87.

Southern Africa Labour and Development Research Unit. National Income Dynamics Study (2012), Wave 3 [dataset]. Version 2.1. Cape Town: Southern Africa Labour and Development Research Unit [producer], 2016. Cape Town: DataFirst [distributor], 2016

Southern Africa Labour and Development Research Unit. National Income Dynamics Study (2010-2011), Wave 2 [dataset]. Version 3.1. Cape Town: Southern Africa Labour and Development Research Unit [producer], 2016. Cape Town: DataFirst [distributor], 2016

Southern Africa Labour and Development Research Unit. National Income Dynamics Study (2008), Wave 1 [dataset]. Version 6.1. Cape Town: Southern Africa Labour and Development Research Unit [producer], 2016. Cape Town: DataFirst [distributor], 2016

Seefeldt, K. (2015). "Constant Consumption Smoothing, Limited Investments, and Few Repayments: The Role of Debt in the Financial Lives of Economically Vulnerable Families". Social Service Review, 89(2): 263-300.

Sorokina, O. (2013) Parental Credit Constraints and Children's College Education, Journal of Family and Economic Issues, Springer, vol. 34(2), pages 157-171, June.

Vaessen, J. (2001) Accessibility of Rural Credit in Northern Nicaragua: The Importance of Networks of Information and Recommendation, Savings and Development, 25(1), $5-31$.

Vicarelli, M. (2010) Exogenous Income Shocks and Consumption Smoothing Strategies among Rural Households in Mexico, in Job Market Paper, Columbia University, New York.

Wooldridge, J. M. (1995). Selection corrections for panel data models under conditional mean independence assumptions. Journal of Econometrics 68, 115-32. 